\title{
Książki dla dzieci i młodzieży w ofercie wydawniczej „Naszej Księgarni”w latach 1921-1939
}

„Nasza Księgarnia” Spółka Akcyjna Związku Nauczycielstwa Polskiego powstała w 1921 roku. Prowadziła działalność księgarsko-wydawniczą, koncentrując się na wydawaniu literatury metodycznej, publikacji z psychologii, pedagogiki i socjologii. Książki skierowane były do nauczycieli i wszystkich, którzy zajmowali się pracą wychowawczą. W ofercie wydawniczej posiadała także podręczniki szkolne oraz książki dla dzieci i młodzieży.

Firma wydawniczo-księgarska powstała jako wyraz potrzeb ówczesnego nauczycielstwa polskiego, które borykało się z problemem braku podręczników i literatury metodycznej dostosowanej do nowych programów oświatowych. Zgodnie ze statutem celem nowej spółki było zaopatrywanie szkolnictwa powszechnego w książki, pomoce naukowe oraz wszelkiego rodzaju wydawnictwa i towary potrzebne dla szkoły. Pracę wydawniczą spółka postanowiła oprzeć na rodzimych autorach, którymi w dużej mierze mieli być doświadczeni nauczyciele-praktycy.

W latach 1921-1939 „Nasza Księgarnia wydała 670 pozycji (655 tytułów) publikacji zwartych. Tabela 1 przedstawia udział poszczególnych kategorii tematycznych w ofercie wydawniczej „Naszej Księgarni” w omawianym okresie.

Prawie połowa publikacji była przeznaczona dla pedagogów i wychowawców, kolejne dwie grupy stanowiły książki dla dzieci i młodzieży oraz podręczniki. Stosunek procentowy poszczególnych kategorii wydawnictw przedstawiał się następująco: książki dla nauczycieli - 48,5\%, książki dla dzieci i młodzieży - 19,7\%, podręczniki - 17,16\%, utwory sceniczne $-4,32 \%$, katalogi wydawnicze i księgarskie $-5,37 \%$, varia $-4,92 \%{ }^{1}$.

* Dr, Uniwersytet Jana Kochanowskiego w Kielcach, Instytut Bibliotekoznawstwa i Dziennikarstwa, Zakład Bibliologii i Informatologii, 25-406 Kielce, ul. Świętokrzyska 21D.

1 Encyklopedia wiedzy o książce podaje, iż w latach 1921-1939 „Nasza Księgarnia” wydała 217 tytułów książek dla nauczycieli, 115 dla dzieci i młodzieży, 44 utwory sceniczne dla teatrów szkolnych oraz 32 podręczniki. Zob. Encyklopedia wiedzy o książce, Wrocław 1971, szp. 1014. Do tych liczb 
Tabela 1. Publikacje zwarte wydane przez „Naszą Księgarnię” w latach 1921-1939a

\begin{tabular}{|l|c|c|c|c|c|c|c|}
\hline $\begin{array}{c}\text { Rok } \\
\text { wydania }\end{array}$ & $\begin{array}{c}\text { Liczba } \\
\text { publikacji } \\
\text { ogółem }\end{array}$ & $\begin{array}{c}\text { Książki dla } \\
\text { nauczycieli }\end{array}$ & $\begin{array}{c}\text { Książki dla } \\
\text { dzieci i mło- } \\
\text { dzieży }\end{array}$ & $\begin{array}{c}\text { Podręcz- } \\
\text { niki }\end{array}$ & $\begin{array}{c}\text { Utwory } \\
\text { sceniczne }\end{array}$ & Katalogi & Varia \\
\hline 1921 & 10 & 1 & 4 & 5 & - & - & - \\
\hline 1922 & 7 & 2 & - & 3 & - & - & 2 \\
\hline 1923 & 1 & 1 & - & - & - & - & - \\
\hline 1924 & 7 & 4 & - & 3 & - & - & - \\
\hline 1925 & 15 & 4 & 3 & 6 & - & 1 & 1 \\
\hline 1926 & 12 & 5 & - & 5 & 1 & 1 & - \\
\hline 1927 & 43 & 12 & 11 & 10 & 6 & 3 & 1 \\
\hline 1928 & 39 & 13 & 9 & 11 & 4 & 2 & - \\
\hline 1929 & 34 & 12 & 8 & 8 & 1 & 5 & - \\
\hline 1930 & 28 & 10 & 5 & 11 & - & 2 & - \\
\hline 1931 & 25 & 13 & - & 10 & - & 1 & 1 \\
\hline 1932 & 29 & 19 & 2 & 5 & - & 2 & 1 \\
\hline 1933 & 38 & 26 & 1 & 7 & - & 3 & 1 \\
\hline 1934 & 50 & 31 & 7 & 5 & 3 & 2 & 2 \\
\hline 1935 & 72 & 39 & 18 & 4 & 8 & - & 3 \\
\hline 1936 & 104 & 63 & 23 & 5 & 5 & 3 & 5 \\
\hline 1937 & 40 & 15 & 14 & 6 & 1 & 2 & 2 \\
\hline 1938 & 70 & 32 & 18 & 10 & - & 4 & 6 \\
\hline 1939 & 46 & 23 & 9 & 1 & - & 5 & 8 \\
\hline Razem & 670 & 325 & 132 & 115 & 29 & 36 & 33 \\
\hline
\end{tabular}

a Obliczeń dokonano po wprowadzeniu do wydanej bibliografii poprawek wynikających z prowadzonych badań.

Źródło: obliczenia własne na podst. M. Olczak-Kardas, Bibliografia wydawnictw zwartych „Naszej Księgarni” Spółki Akcyjnej Związku Nauczycielstwa Polskiego za lata 1921-1939, Kielce 2005.

można jeszcze dodać 34 tytuły książek różnych, 12 map i innych pomocy naukowych - łącznie cała działalność wydawnicza tamtego okresu to 454 tytuły (z czego 442 to wydawnictwa zwarte). Zob. „Nasza Księgarnia" 40 lat działalności dla dziecka i szkoły, Warszawa 1961, s. 14. W niniejszym artykule posłużono się ustaleniami autorki, która w bibliografii wydawnictw zwartych „Naszej Księgarni” zidentyfikowała 670 pozycji, na które złożyło się 655 tytułów. Liczba ta wymaga komentarza w stosunku do dotychczas podawanych wielkości. Różnice mogą wynikać z kilku powodów: w bibliografii uwzględniono katalogi wydawnicze i księgarskie „Naszej Księgarni”, których być może nie włączano do ogólnej liczby wydawnictw; nieznany jest sposób traktowania wydawnictw tomowych (w bibliografii część lub tom liczono jako odrębną publikację wtedy, kiedy posiadał własny tytuł lub - w przypadku podręcznika - przeznaczony był dla innej klasy). Trzecią przyczyną może być odmienne podejście do odbitek z Encyklopedii wychowania, które we wspomnianej bibliografii były traktowane jako samodzielne wydawnictwa. Zob. M. Olczak-Kardas, Bibliografia wydawnictw zwartych „Naszej Księgarni” Spółki Akcyjnej Związku Nauczycielstwa Polskiego za lata 1921-1939, Kielce 2005. 
W artykułach z tego okresu pedagodzy i wychowawcy młodego pokolenia Polaków zwracali uwagę na braki występujące na rynku książki dla dzieci i młodzieży. Szczególnie w początkowym okresie, kiedy produkcja wydawnicza nie była w stanie zaspokoić potrzeb społeczeństwa. Zwracano również uwagę na konieczność zmian treści, a tym samym wartości, które niosła ze sobą książka dla młodego odbiorcy. Wielu pedagogów, zarówno teoretyków jak i praktyków, zwracało uwagę na zmieniające się podejście do życia ówczesnej młodzieży. Nowa sytuacja wywołała potrzebę przeobrażeń także w literaturze dla dzieci i młodzieży. Książki miały wspomagać proces dydaktyczno-wychowawczy i uczyć funkcjonowania w nowej rzeczywistości.

Przykładem tego typu rozważań może być kilka tekstów opublikowanych na łamach „Pracy Szkolnej”. Na ten temat wypowiadali się m.in. Józef Gołąbek, Stanisław Bełżecki, Benedykt Kubski, Stanisława Prusowa.

J. Gołąbek w swoim artykule z 1928 roku² zwrócił uwagę, że polska myśl teoretyczna dotycząca literatury dla młodzieży była bardzo uboga w porównaniu z innymi krajami. Próbował również znaleźć przyczyny złego stanu na rynku wydawniczym literatury dla dzieci i młodzieży w Polsce. Wymienił m.in. brak odpowiedniej krytyki literackiej, przestarzałą tematykę utworów dla młodzieży, która nie odpowiadała potrzebom i współczesnej sytuacji, a także zbyt małą liczbę tytułów napisanych ładnym literackim językiem. J. Gołąbek apelował do polskich autorów o dobre teksty dla młodych Polaków.

W 1929 roku ukazał się w dwóch częściach artykuł S. Bełżeckiego³. Tekst był podobny w wydźwięku do poprzedniego, ale autor mocniej powiązał temat literatury dziecięco-młodzieżowej ze szkołą i jej misją wychowawczą. Opisywał dwa obozy wśród nauczycieli - konserwatystów i grupę starającą się stworzyć nową szkołę na miarę czasów. Te stanowiska przekładały się także na stosunek do literatury dla młodzieży. Moralizatorskie, mocno religijne książki, opiewające patriotyzm i walkę o wolność, stawiał w opozycji do tekstów o dniu teraźniejszym, świetlanej przyszłości i nowinkach naukowo-technicznych. Autor uważał, że młodemu czytelnikowi nie są już potrzebne teksty o „uciemiężonej” ojczyźnie, fantastyczne opowieści czy moralizatorskie teksty, które ze względu na swoją treść nie zachęcały do czytania. S. Bełżecki był zwolennikiem radosnej szkoły i takiej literatury oczekiwał dla młodzieży.

S. Bełżecki powoływał się w swoich rozważaniach na artykuł B. Kubskiego ${ }^{4}$, opublikowany w 1927 roku, który dotyczył czytanek o treści moralnej. B. Kubski przeanalizował zawartość tego typu tekstów we wszelkiego rodzaju wypisach i podręcznikach dla dzieci i młodzieży. Próbował odpowiedzieć na pytanie, czy taki sposób przekazywania zasad moralnych odnosi zamierzony efekt. W konkluzji odrzucił potrzebę istnienia tekstów moralizatorskich w podręcznikach, wykazując uprzednio w wielu konkretnych przypadkach ich niewłaściwy wpływ na kształtowanie dziecięcej psychiki i moralności.

2 J. Gołąbek, Literatura dla młodzieży, „Praca Szkolna” 1928, nr 9, s. 270-275.

${ }^{3}$ S. Bełżecki, O książkę dla młodzieży, „Praca Szkolna” 1929, nr 8, s. 232-238; tenże, O książkę dla młodzieży. Dokończenie, „Praca Szkolna” 1929, nr 9, s. 279-282.

${ }^{4}$ B. Kubski, Czytanki treści moralnej, „Praca Szkolna” 1927, nr 1, s. 23-27. 
O dobrej i złej książce pisała w swoim artykule S. Prusowa ${ }^{5}$. Rozpatrywała ją jako czynnik wychowania - dodatni bądź ujemny. Autorka określiła kryteria treściowe i formalne uznania książki za dobrą. Wymieniła je, omówiła i ustosunkowała się do nich, a także wyraziła nasuwające się wątpliwości. Treść książek dla dzieci winna być według S. Prusowej dostępna, pogodna i moralna, język poprawny i przejrzysty, a styl jasny. Autorka stwierdziła, że wartość książki zależy również od dziecięcego czytelnika. Zachęcała, aby wychowawca uczestniczył w procesie czytania, podsuwał książki, rozmawiał o nich, zwracał uwagę na to, co w nich dobre, a co złe. W wyniku tych działań dziecko powinno nauczyć się rozróżniania dobrej książki.

Analizując wyrywkowe dane statystyczne z końca lat dwudziestych, daje się zauważyć, że książki dla dzieci i młodzieży stanowiły niewielki odsetek produkcji wydawniczej polskich firm. W 1925 roku było to 4,72\% wszystkich druków nieperiodycznych w języku polskim ${ }^{6}$. W 1926 roku kategoria ta obejmowała 3,58\% wszystkich druków nieperiodycznych wydanych w języku polskim, a średni nakład wynosił wówczas 6055 egz. ${ }^{7}$ Rok 1927 przyniósł wzrost ogólnej produkcji do 4,9\%, zmniejszył się jednak średni nakład - do 4158 egz. ${ }^{8}$

Wobec niewystarczającej oferty i niebezpieczeństwa funkcjonowania na rynku nieodpowiedniej dla młodych czytelników literatury, należało wprowadzić zewnętrzny nadzór nad tego typu publikacjami. W dwudziestoleciu międzywojennym szczególną rolę odegrała powołana w 1923 roku przez Ministra Wyznań Religijnych i Oświecenia Publicznego, na mocy rozporządzenia z dnia 28 listopada, Komisja do oceny książek do czytania dla młodzieży szkolnej ${ }^{9}$. W składzie Komisji znalazło się 21 osób, przewodniczącym został Tadeusz Łopuszański, a jego zastępcą Zygmunt Ziembiński. Ocenie miały podlegać książki i czasopisma odpowiednie dla młodzieży szkół powszechnych, średnich ogólnokształcących, seminariów nauczycielskich i szkół zawodowych. Nie musiały być to tylko publikacje pisane dla młodzieży, ale także i te, które mogły stać się taką lekturą ze względu na korzyści płynące z ich czytania. Książki miały być przeczytane przez jak największą liczbę osób z Komisji. Kolejnym etapem była dyskusja i wydanie oceny, która powinna być jednoznaczna i zawierać się w jednym z terminów: książka „konieczna”, „pożądana”, „dozwolona” i „niedozwolona” w bibliotece szkolnej. Oprócz tego należało zaznaczyć kategorię szkoły i wiek, dla którego była przeznaczona. Orzeczenia Komisji stanowiły jedynie opinię. Prawomocne stawały się dopiero po zatwierdzeniu przez Podsekretarza Stanu.

5 S. Prusowa, Dobra i zła książka. Refleksje i materiał do dyskusji, „Praca Szkolna” 1928, nr 2, S. $37-41$.

6 S. Pliszczyński, Statystyka porównawcza produkcji wydawniczej druków nieperiodycznych w latach ubiegłych, „Przegląd Księgarski” 1928, nr 21, s. 326.

7 W. Raczkowski, Statystyka produkcji wydawniczej druków nieperiodycznych w r. 1926, „Przegląd Księgarski” 1927, nr 14, s. 332.

8 S. Pliszczyński, Produkcja książek w r. 1927 według nakładu, „Przegląd Księgarski” 1929, nr 15, s. 242.

9 Rozporządzenie Ministra Wyznań Religijnych i Oświecenia Publicznego z dnia 28 listopada 1923 roku w sprawie utworzenia Komisji do oceny książek do czytania dla młodzieży szkolnej, „Dz. Urz. Ministerstwa Wyznań Religijnych i Oświaty Pozaszkolnej” 1923, nr 21, poz. 187. 
Oceny i orzeczenia miały być ogłaszane w Bibliografii Pedagogicznej (można było zamieszczać jednostkowe oceny, z wyjątkiem opinii o książkach niedozwolonych, których nie podawano do wiadomości). W 1927 roku rozporządzeniem Ministra WRiOP zmieniono skład Komisji, przewodniczący i zastępca pozostali bez zmian ${ }^{10}$.

W Zarządzeniu Ministra WRiOP z 1929 roku ${ }^{11}$ podano, jakie aspekty należało brać pod uwagę przy kwalifikowaniu książek. W przypadku literatury pięknej przeprowadzano ocenę pod względem literackim, wychowawczym, higienicznym i estetycznym. Literaturę popularnonaukową oceniano w aspekcie naukowym, dydaktyczno-wychowawczym, językowym i stylistycznym, a także higienicznym i estetycznym. Opiniowanie beletrystyki należało do Komisji oceny książek z zakresu literatury pięknej do czytania dla młodzieży ${ }^{12}$, a literatury popularnonaukowej do Komisji do spraw książek szkolnych. Dodatkowo wymagane były dwie recenzje.

„Nasza Księgarnia” jako wydawca książek dla dzieci i młodzieży nie należała do przodujących firm. Istniało kilka dużych oficyn, które publikowały znacznie więcej tego typu literatury (np. Gebethner i Wolff, M. Arct) i dysponowały większymi możliwościami ${ }^{13}$. Spółka posiadała jednak bardzo ważny atut. Polityką wydawniczą firmy kierowały osoby związane bezpośrednio ze światem dzieci i młodzieży, znające jego potrzeby. Atrybutem wydawnictwa był stały kontakt z gronem pedagogicznym, a za jego pośrednictwem z uczniami i ich rodzicami. Fakt, że książki wychodziły niejako pod patronatem Związku Nauczycielstwa Polskiego, pozwalał na zwiększenie możliwości powodzenia na rynku księgarskim.

Książki dla dzieci i młodzieży pojawiły się w ofercie wydawniczej „Naszej Księgarni” już w pierwszym roku istnienia firmy. Ogółem w latach 1921-1939 opublikowano 131 tytułów (132 publikacje). Stanowiło to $20 \%$ wszystkich wydanych tytułów (19,7\% całej produkcji wydawniczej). Szczegółowy rozkład w kolejnych latach przedstawia tabela 2.

W latach 1922-1924, 1926, 1931 nie opublikowano żadnej książki dla tej grupy odbiorców. W pozostałych produkcja wahała się od 1 tytułu w 1933 roku, co stanowiło $2,7 \%$ wszystkich wydanych w tym roku, do 23 w 1936 roku $(22,54 \%)$. Rok 1936 był także najlepszy w dziejach wydawnictwa, jeżeli chodzi o liczbę publikacji w ogóle. Największy udział procentowy książek dla dzieci i młodzieży odnotowano w 1921 roku - 44,4\% oraz w 1937 roku - 35\% całej produkcji. Najmniejszy odsetek wystąpił w wymienionym roku 1933.

10 Rozporządzenie Ministra Wyznań Religijnych i Oświecenia Publicznego z dnia 8 stycznia 1927 r. w sprawie Komisji oceny książek do czytania dla młodzieży szkolnej, „Dz. Urz. Ministerstwa Wyznań i Oświecenia Publicznego" 1927, nr 3, poz. 40.

11 Zarządzenie Ministra Wyznań Religijnych i Oświecenia Publicznego z dnia 20 listopada 1929 r. w sprawie oceny książek do czytania dla młodzieży, „Dz. Urz. Ministerstwa Wyznań i Oświecenia Publicznego" 1929, nr 13, poz. 187.

12 Zob. Skład osobowy Komisji oceny książek z zakresu literatury pięknej do czytania dla młodzieży, „Dz. Urz. Ministerstwa Wyznań i Oświecenia Publicznego” 1930, nr 3, poz. 43.

13 Dotkliwy kryzys w dziedzinie książek dla dzieci, „Dla Szkoły i Nauczyciela” 1932, nr 8, s. 24-25. 
Tabela 2. Książki dla dzieci i młodzieży wydane przez „Naszą Księgarnię w latach 1921-1939

\begin{tabular}{|c|c|c|c|c|}
\hline Rok wydania & $\begin{array}{l}\text { Publikacje } \\
\text { (ogółem) }\end{array}$ & $\begin{array}{c}\text { Tytuły } \\
\text { (ogółem) }\end{array}$ & $\begin{array}{l}\text { Polscy autorzy } \\
\text { (liczba tytułów) }\end{array}$ & $\begin{array}{l}\text { Tłumaczenia } \\
\text { (liczba tytułów) }\end{array}$ \\
\hline 1921 & 4 & 4 & 4 & - \\
\hline 1922 & - & - & - & - \\
\hline 1923 & - & - & - & - \\
\hline 1924 & - & - & - & - \\
\hline 1925 & 3 & 3 & 2 & 1 \\
\hline 1926 & - & - & - & - \\
\hline 1927 & 11 & 10 & 4 & 6 \\
\hline 1928 & 9 & 9 & 7 & 2 \\
\hline 1929 & 8 & 8 & 7 & 1 \\
\hline 1930 & 5 & 5 & 4 & 1 \\
\hline 1931 & - & - & - & - \\
\hline 1932 & 2 & 2 & 2 & - \\
\hline 1933 & 1 & 1 & - & 1 \\
\hline 1934 & 7 & 7 & 7 & - \\
\hline 1935 & 18 & 18 & 16 & 2 \\
\hline 1936 & 23 & 23 & 23 & - \\
\hline 1937 & 14 & 14 & 13 & 1 \\
\hline 1938 & 18 & 18 & 17 & 1 \\
\hline 1939 & 9 & 9 & 8 & 1 \\
\hline Razem & 132 & 131 & 114 & 17 \\
\hline
\end{tabular}

Źródło: obliczenia własne na podst. M. Olczak-Kardas, Bibliografia wydawnictw zwartych „Naszej Księgarni” Spółki Akcyjnej Związku Nauczycielstwa Polskiego za lata 1921-1939, Kielce 2005.

W większości twórcami tekstów byli polscy autorzy - 87,2\%. Była to ogólna tendencja, występująca w odniesieniu do całej produkcji wydawniczej firmy - 92,21\%. Tłumaczenia zajmowały jedynie $12,97 \%$ oferty dla dzieci i młodzieży. Większość tytułów to pierwsze wydania - 82,44\%, kolejne stanowiły 17,55\%. W seriach przeznaczonych dla młodego czytelnika ukazało się 31,29\% tytułów.

W sprawozdaniu ZNP z 1930 roku, analizującym działalność „Naszej Księgarni” w drugim półroczu 1928 roku i 1929 roku, podkreślono, że w okresie tym powstało wiele wartościowych książek dla dzieci i młodzieży, napisanych przez wybitnych autorów. Jednak wyraźnie dał się zauważyć zastój w sprzedaży. Wyliczono, że stosunek sprzedaży książek dla nauczycieli do liczby książek dla dzieci i młodzieży wynosił 4:1. Próbowano znaleźć powody tego stanu rzeczy. Uważano, że miało na to wpływ m.in. ciągłe dokształcanie się nauczycieli, niewielkie fundusze na kompletowanie uczniowskich bibliotek szkolnych, a także działalność 
MWRiOP, które przez dwa lata nie oceniło nowych tytułów dla dzieci i nie wydało na ich temat opinii ${ }^{14}$.

Artykuł Dotkliwy kryzys w dziedzinie książek dla dzieci ${ }^{15}$, zamieszczony w biuletynie „Dla Szkoły i Nauczyciela” z 1932 roku, opisywał trudności, jakie dotknęły książkę dla dzieci. W ostatnich latach widać było zastój w jej sprzedaży. Spadek zanotowano również w handlu podręcznikami, w stosunku do roku 1931 było to $15-20 \%$. Najlepiej sprzedające się książki dla dzieci nie osiągnęły nawet 1000 sprzedanych egzemplarzy (J. Porazińska, Hej z drogil; E. Szelburg-Zarembina, Zuch). Średnia liczba sprzedanych egzemplarzy tytułu książki dziecięcej wynosiła 200 sztuk.

Analizując dostępne dane dotyczące nakładów książek dla dzieci i młodzieży wydawanych przez „Naszą Księgarnię”, ustalono, że firma nie odbiegała od średniej krajowej dla tego typu wydawnictw. Nakłady wynosiły od 1000 do 5700 egzemplarzy ${ }^{16}$. Średni nakład dla tej kategorii odbiorców w Polsce to 4269,56 egzemplarzy.

Książki dla dzieci i młodzieży wydawane przez „Naszą Księgarnię” podlegały ocenie wspomnianej powyżej Komisji ministerialnej. W wykazach z 1926 i 1927 roku brak publikacji „Naszej Księgarni” ${ }^{17}$. W IV wykazie zamieszczono jedną pozycję - Stefanii Baczyńskiej, którą uznano za pożądaną dla klas 1-2 szkoły powszechnej18. W V wykazie z 1928 roku pojawiły się 3 książki wydane przez spółkę ${ }^{19}$ : E. Szelburg-Zarembiny - oceniona jako pożądana w klasach 1-4 szkoły powszechnej i w klasie pierwszej szkoły średniej ${ }^{20}$; B. Pawłowicza - jako dozwolona w klasach 5-6 szkoły powszechnej i w klasie drugiej szkoły średniej ${ }^{21}$ oraz

14 Związek Polskiego Nauczycielstwa Szkół Powszechnych. Sprawozdanie z działalności związku za Il-gie półrocze 1928 i rok 1929, Warszawa 1930.

15 Dotkliwy kryzys...

16 Obliczeń dokonano na podstawie wyrywkowych danych.

17 Okólnik Ministerstwa Wyznań Religijnych i Oświecenia Publicznego do Kuratoriów Okręgów Szkolnych oraz Śląskiego Urzędu Wojewódzkiego w sprawie książek, poleconych do bibliotek dla młodzieży szkolnej. Załącznik II - Wykaz książek, poleconych przez Komisję do oceny książek do czytania dla młodzieży szkolnej przy Ministerstwie Wyznań Religijnych i Oświecenia Publicznego w czasie od dnia 1 maja 1925 do 1 maja 1926, Dz. Urz. MWRiOP 1926, nr 12, poz. 145; Okólnik Ministerstwa Wyznań Religijnych i Oświecenia Publicznego do Kuratoriów Okręgów Szkolnych i Śląskiego Urzędu Wojewódzkiego w Katowicach w sprawie książek, poleconych do bibliotek dla młodzieży szkolnej. Załącznik III - Wykaz książek, poleconych przez Komisję oceny książek do czytania dla młodzieży szkolnej przy Ministerstwie Wyznań Religijnych i Oświecenia Publicznego w czasie od dnia 1 maja 1926 do 31 stycznia 1927, Dz. Urz. MWRiOP 1927, nr 4, poz. 54.

18 Okólnik Ministerstwa Wyznań Religijnych i Oświecenia Publicznego do Kuratoriów Okręgów Szkolnych i Śląskiego Urzędu Wojewódzkiego w Katowicach w sprawie książek, poleconych do bibliotek dla młodzieży szkolnej. Załącznik IV - Wykaz książek, poleconych przez Komisję oceny książek do czytania dla młodzieży szkolnej przy Ministerstwie Wyznań Religijnych i Oświecenia Publicznego (w czasie od dnia od 31 stycznia 1927 do dnia 1 lipca 1927, Dz. Urz. MWRiOP 1927, nr 12, poz. 208. Dotyczy książki - S. Baczyńska, Wacek i sześć jego siostrzyczek, Warszawa 1927.

19 Okólnik Ministerstwa Wyznań Religijnych i Oświecenia Publicznego do Kuratoriów Okręgów Szkolnych i Śląskiego Urzędu Wojewódzkiego w Katowicach oraz do Liceum Krzemienieckiego w Krzemieńcu w sprawie książek poleconych przez Komisję oceny książek do czytania dla młodzieży szkolnej. Załącznik V - Wykaz książek, poleconych przez Komisję oceny książek do czytania dla młodzieży szkolnej przy Ministerstwie Wyznań Religijnych i Oświecenia Publicznego (w czasie od dnia 1 lipca 1927 do dnia 30 kwietnia 1928, Dz. Urz. MWRiOP 1928, nr 7, poz. 120.

20 E. Szelburg-Zarembina, Najmilsi, Warszawa 1928.

${ }^{21}$ B. Pawłowicz, Franek na szerokim świecie. Przygody na morzu i lądzie, Warszawa 1928 [Właśc. 1927]. 
E. Selousa z adnotacją - dozwolona dla klas 3-4 szkoły powszechnej i pierwszej klasy szkoły średniej22.

Halina Skrobiszewska, w swojej książce o Hannie Januszewskiej ${ }^{23}$, zwróciła uwagę na znaczącą rolę opinii komisji oceny książek przy MWRiOP. Jej zdaniem była ona ważniejsza od recenzji w czasopismach, gdyż to tu zapadały decyzje, czy książka będzie polecona do bibliotek szkolnych. Dawało to ogromne możliwości wydawcy w kwestii nakładu. Jeżeli książka zgłoszona była do oceny w formie maszynopisu, po werdykcie wstępnym Komisji wydawca wiedział, jaki nakład książki może przygotowywać. Możliwość sprzedaży do bibliotek szkolnych dawała szansę na większe zyski. Wydawcy szukali do współpracy pisarzy, którzy mogli zagwarantować finansowy sukces ${ }^{24}$.

H. Skrobiszewska podkreśliła jeszcze, że również wydawca dawał możliwość powodzenia tekstom. W przypadku Hanny Januszewskiej zmiana wydawcy przyniosła większą popularność tekstu ${ }^{25}$. „Nasza Księgarnia” była wydawnictwem gwarantującym dotarcie tomiku do szkół, czyli najszerszego kręgu odbiorców. Podkreślono nisko skalkulowaną cenę, która także miała wpływ na popularność książki ${ }^{26}$. H. Skrobiszewska uważała, że siłą utworu Siwa gąska, siwa..., który wydała spółka, był współczesny wiejski folklor nastawiony na odbiorcę dziecięcego - dziecięcy bohater i dziecięce widzenie świata ${ }^{27}$. Najprawdopodobniej ten aspekt przesądził o decyzji wydawnictwa.

„Nasza Księgarnia” wydawała w omawianym okresie sześć tytułów serii przeznaczonych dla młodego odbiorcy. Miały one zarówno charakter popularnonaukowy, jak i beletrystyczny ${ }^{28}$. Serie dla dzieci i młodzieży pojawiły się w ofercie wydawniczej w 1929 roku i po krótkiej przerwie od 1934 roku były nieprzerwanie obecne do 1939 roku w planie wydawniczym firmy.

Tabela 3. Serie wydawnicze dla dzieci i młodzieży wydane przez „Naszą Księgarnię” w latach 1921-1939a

\begin{tabular}{|l|c|c|c|c|c|c|}
\hline $\begin{array}{c}\text { Rok } \\
\text { wydania }\end{array}$ & "Czytamy" & $\begin{array}{c}\text { "Nasz Zwie- } \\
\text { rzyniec" }\end{array}$ & $\begin{array}{c}\text { "Opowiada- } \\
\text { nia Histo- } \\
\text { ryczne" }\end{array}$ & $\begin{array}{c}\text { "Opowieści } \\
\text { Przyrodni- } \\
\text { cze” }\end{array}$ & $\begin{array}{c}\text { "Przymierze } \\
\text { zsiążką. Biblio- } \\
\text { teka Młodzieży” }\end{array}$ & $\begin{array}{c}\text { "Ze Świata } \\
\text { Przyrody" }\end{array}$ \\
\hline 1921 & - & - & - & - & - & - \\
\hline 1922 & - & - & - & - & - & - \\
\hline 1923 & - & - & - & - & - & - \\
\hline 1924 & - & - & - & - & - & - \\
\hline
\end{tabular}

22 E. Selous, Przymierze Tomcia ze zwierzętami, wyd. 3, Warszawa 1928.

23 H. Skrobiszewska, O Hannie Januszewskiej, Warszawa 1987.

24 Tamże, s. 38-39.

25 Dotyczy książki: H. Januszewska, Siwa gąska, siwa..., Warszawa 1939.

26 H. Skrobiszewska, O Hannie..., s. 63.

27 Tamże, s. 65.

28 Zob. B. Staniów, Serie książek popularnonaukowych dla dzieci i młodzieży w Polsce międzywojennej jako źródło informacji o świecie, nauce i człowieku (na wybranych przykładach), [w:] Przestrzeń informacyjna książki, red. J. Konieczna, S. Kurek-Kokocińska, H. Tadeusiewicz, Łódź 2009, s. $339-353$. 


\begin{tabular}{|c|c|c|c|c|c|c|}
\hline 1925 & - & - & - & - & - & - \\
\hline 1926 & - & - & - & - & - & - \\
\hline 1927 & - & - & - & - & - & - \\
\hline 1928 & - & - & - & - & - & - \\
\hline 1929 & - & 3 & - & - & - & - \\
\hline 1930 & - & - & - & - & - & - \\
\hline 1931 & - & - & - & - & - & - \\
\hline 1932 & - & - & - & - & - & - \\
\hline 1933 & - & - & - & - & - & - \\
\hline 1934 & 4 & - & - & - & - & - \\
\hline 1935 & - & - & 1 & 2 & 2 & 2 \\
\hline 1936 & - & - & - & 6 & 1 & 3 \\
\hline 1937 & - & - & - & 4 & - & 1 \\
\hline 1938 & - & - & - & 7 & - & 2 \\
\hline 1939 & - & - & - & 3 & - & - \\
\hline Razem & 4 & 3 & 1 & 22 & 3 & 8 \\
\hline
\end{tabular}

a Podano liczbę publikacji ogółem, w tym kolejne wydania.

Źródło: obliczenia własne na podst.: M. Olczak-Kardas, Bibliografia wydawnictw zwartych „Naszej Księgarni” Spółki Akcyjnej Związku Nauczycielstwa Polskiego za lata 1921-1939, Kielce 2005.

„Nasz Zwierzyniec” to pierwsza seria spółki skierowana do młodego odbiorcy. Wydawana pod redakcją Delfiny Gayówny, przy współudziale Polskiego Przyrodniczego Towarzystwa Pedagogicznego, powołanego do życia w Warszawie 15 lipca 1925 roku uchwałą Sekcji Przyrodniczo-Dydaktycznej XII Zjazdu Lekarzy i Przyrodników. Cele, jakie przyświecały temu towarzystwu, to: organizowanie pracy nauczycieli w zakresie dydaktyki przyrodoznawstwa i ułatwienie kontaktu ze światem naukowym; obrona stanowiska przyrodoznawstwa w szkole i uprawnień nauczyciela przyrody. Jeden z punktów brzmiał: „Tworzenie praktycznych podstaw nauczania przyrody w postaci: wydawnictw dla nauczyciela i młodzieży, zakładania ogrodów szkolnych, organizacji wycieczek"29. W swoim statucie Towarzystwo zwracało uwagę także na szerzenie zamiłowania do przyrody wśród całego społeczeństwa, ze szczególnym uwzględnieniem młodzieży. Jako sposoby działania wymieniono m.in. współdziałanie z MWRiOP, a także innymi instytucjami i organizacjami w realizacji celów Towarzystwa oraz oddziaływanie na opinię publiczną poprzez publikacje i prasę. Mówiono o wydawaniu własnego organu prasowego, a także o popieraniu wydawnictw pokrewnych ${ }^{30}$. Współpraca z „Naszą Księgarnią” przy wydawaniu serii była realizowaniem założonych przez Towarzystwo celów.

Seria miała popularyzować wiedzę przyrodniczą poprzez podawanie opisów zwierząt znajdujących się w polskich ogrodach zoologicznych. Ilustracje w nich

${ }_{29}$ H. Michcińska, Żubr, Warszawa 1930, s. 31.

30 Statut Polskiego Przyrodniczego Towarzystwa Pedagogicznego, Warszawa 1930, s. 4-5. 
zawarte dawały możliwość poznania zwierząt tym, którzy nie mieli szans na zwiedzanie ogrodu zoologicznego. Były to niewielkie książeczki - format $15 \mathrm{~cm}$, objętość 30-40 stron, ilustrowane. Ukazały się trzy numery, wszystkie w 1929 roku. Ich twórcami byli polscy autorzy: Helena Michcińska, Jan Sokołowski i Jadwiga Viewegerowa. Na łamach „Głosu Nauczycielskiego” zapowiadano jeszcze jeden tytuł - Lis Z. Federowicza. Najprawdopodobniej książka nie ukazała się. Cena za tom wynosiła 60 groszy $^{31}$. Nakład wynosił 5300-5500 egzemplarzy ${ }^{32}$.

W 1934 roku ukazały się 4 numery serii „Czytamy”: Łatwe, ilustrowane książeczki do czytania w domu i w szkole w I-szym i w Il-gim roku nauczania. Autorkami były: Aleksandra Dargielowa, Lucyna Krzemieniecka, Anna Oderfeldówna i Janina Wuttkowa. Ilustracje stworzyli: Jerzy Radlicz, Wanda Zawidzka i Stanisław Łuckiewicz. Na podstawie dotychczasowych materiałów nie udało się ustalić, czy zostały wydane: nr 5 - Zwierzęta i nr 6 - Ulica ${ }^{33}$. Wszystkie części w formacie $23 \mathrm{~cm}$, o objętości 15 stron, ozdobione ilustracjami. Cena 30 groszy, nakład - 5700 (nr 1), 2000 (nr 2), 2200 (nr 3), 3300 (nr 4) egzemplarzy ${ }^{34}$.

W tym przypadku problematyczne jest zaklasyfikowanie tych wydawnictw. Nie ma potwierdzenia, czy była to seria, czy może należałoby je zakwalifikować jako podręczniki szkolne. Najbardziej trafnym rozwiązaniem jest chyba uznanie ich za książki pomocnicze, z których mogły korzystać dzieci uczące się czytać zarówno w szkole, jak i w domu. Książeczki dostosowane były do kolejnych etapów nauki czytania, zawierały bardzo łatwe teksty (w pierwszych numerach eliminujące np. trudniejsze wyrazy, a nawet występowanie dwuznaków i zmiękczeń). Szybszemu przyswojeniu tekstu miały służyć rymowane wierszyki, które dziecko łatwiej odbierało i zapamiętywało. Książeczki były przygotowane tak, aby dzieci mogły korzystać z nich same lub z pomocą rodziców, nauczyciela, a nawet starszych kolegów. Tam, gdzie pozwalały na to warunki materialne, dzieci mogły pisać w książce, w której zostawiono puste miejsca, np. na dokończenie zdań35.

"Opowieści Przyrodnicze" zaczęły ukazywać się od 1935 roku i nieprzerwanie wydawano je do roku 1939. Ogółem ukazały się 22 pozycje (18 tytułów). Tylko dwa tytuły były tłumaczeniami ${ }^{36}$. Seria wychodziła pod redakcją Zofii Bohuszewiczówny. Była skierowana do młodszych dzieci ${ }^{37}$. Autorzy to: Helena Grotowska, Antonina Żabińska, Feliks Burdecki, Czesław Centkiewicz, Bohdan Dyakowski, Maria Kasperowiczowa, Jan Bogumił Sokołowski, Halina Jaczewska, Jadwiga Wernerowa, Emilia Birnbaum, Alicja Dorabialska, Włodzimierz Durow. Okładki w większości projektował Konstanty Sopoćko. Ilustrowały Halina Maszyńska i Ewa Śliwińska.

31 „Nasz Zwierzyniec”, „Głos Nauczycielski” 1929, nr 33, s. 524.

32 Brak danych o nakładzie dla numeru 1 serii.

33 Zabawki, Warszawa 1934.

${ }^{34}$ Ceny i nakłady podawane w artykule są dla wielu wydawnictw niepełne, bowiem do dyspozycji są tylko wyrywkowe dane. W przypadku cen utrudnienie polega dodatkowo na tym, że pochodzą z różnych okresów, a więc nie są w pełni porównywalne, co zmniejsza ich wartość do analiz, ale nie umniejsza ich wartości informacyjnej wobec tak nielicznych źródeł.

35 Zabawki...

36 V. Durov, Bebi, Warszawa 1938; tenże, Mimuś, Warszawa 1939.

37 „Kalendarz Nauczycielski” 1939, s. 271. 
Poszczególne tomy miały objętość 29-71 stron, w formacie 20-21 cm. Dwa tytuły doczekały się kolejnych wydań: H. Grotowskiej Mechanik Jur - cztery wydania i A. Żabińskiej Jak białowieskie rysice zostały warszawiankami - dwa wydania. Tematyka tych niewielkich książeczek dotyczyła świata przyrody. Podana w przystępny i zrozumiały dla młodego odbiorcy sposób. Można wymienić m.in. takie tematy, jak życie zwierząt, krainy geograficzne w Polsce i na świecie. Cena egzemplarza wahała się od 70 groszy do 1 złotego i 60 groszy. Nakład 3200 egzemplarzy.

W latach 1935-1938 ukazywała się seria „Ze Świata Przyrody”, również pod redakcją Zofii Bohuszewiczówny. Wydano 9 numerów ${ }^{38}$. Jeden tytuł tłumaczony (tekst Augusta Piccarda), pozostałe napisali autorzy polscy: Tekla Cygowa, Halina Karmazyńska-Przewalska, Jan Dembowski, Antoni Bolesław Dobrowolski, Jan Bogumił Sokołowski, Karolina Lublinerówna ${ }^{39}$, Irena Dąbkowska, Marian Sokołowski. Ilustracje wykonali: N. Karmazyńska-Wdowiszewska, Janina Tyszkiewiczowa, M. Zajączkowski, Z. Wyszyński, Alina Chylińska. Okładkę do kilku numerów projektował Bolesław Bakke.

W tym przypadku seria opisywana była w recenzjach dwojako - jako książki dla dzieci i młodzieży oraz dla nauczycieli. W katalogu „Naszej Księgarni” z 1938 roku była umieszczona w dziale Książki dla dzieci i młodzieży z przeznaczeniem dla starszej młodzieży. Pod koniec spisu pojawiła się adnotacja: „Książeczki przyrodnicze opracowane przez pierwszorzędnych znawców poszczególnych zagadnień, wydane w ładnej szacie zewnętrznej stanowią doskonałą pomoc w pracy szkolnej i miłą lekturę domową ucznia” 40 . W „Kalendarzu Nauczycielskim” również pojawiła się adnotacja, że seria przeznaczona była dla starszej młodzieży ${ }^{41}$.

Poszczególne tomy były zróżnicowane pod względem objętości -47-166 stron. Format $21 \mathrm{~cm}$, ilustrowane, z zastosowaniem tablic. Cena wahała się od 1 złotego i 10 groszy do 2 złotych i 50 groszy. Nakład wynosił 3300 egzemplarzy ${ }^{42}$.

W serii „Opowiadania Historyczne” ukazał się tylko pierwszy numer - tekst autorstwa Jerzego Rychlińskiego Był bój pod Oliwą - wydany w 1935 roku. Nie ma żadnych wzmianek o jej kontynuacji przez inną firmę wydawniczą. Cena tytułu - 2 złote 30 groszy. Nakład - 4200 egzemplarzy.

„Przymierze z Książką. Biblioteka Młodzieży” to seria, której tylko trzy tomy ukazały się nakładem „Naszej Księgarni” (t. 7, 8, 9). Dwa tytuły w 1935 roku i jeden w 1936 roku. Wszystkie były dziełem polskich autorek: Heleny Boguszewskiej, Heleny Radlińskiej, Wandy Wasilewskiej. Seria wychodziła pod redakcją Jana Muszkowskiego. Objętość tomów 125-144 strony, format 19-20 cm. Cena od 1 złotego i 80 groszy do 2 złotych i 60 groszy. Nakład 3200-4200 egzemplarzy.

${ }^{38} \mathrm{~W}$ oparciu o dostępne materiały nie ustalono, czy zapowiadane w katalogu wydawnictwa z 1938 roku: nr 8 - J. Lilpop, Roślinność epok minionych i nr 10 - K. Lublinerówna, Mech płonnik i mech torfowiec, które miały status „w druku”, zostały opublikowane. W opracowanej bibliografii udało się opisać jedynie numery 1-7 i 9.

39 Karolina Lubliner-Mianowska.

40 Mały katalog wydawnictw własnych 1938, Warszawa 1938, s. 48.

41 „Kalendarz Nauczycielski”...

42 Informacja tylko dla jednego tytułu. 
Do niniejszych rozważań należałoby dodać kilka słów o utworach scenicznych w repertuarze "Naszej Księgarni”. Były to teksty wspomagające pracę dydaktyczno-wychowawczą pedagogów, ale ich treść była przeznaczona dla odbiorcy dziecięcego i młodzieżowego. Utwory sceniczne znalazły się w repertuarze wydawniczym spółki w 1926 roku $^{43}$. Większość z nich była opracowana w sposób pozwalający na ich inscenizację w szkołach i innych placówkach wychowawczych. Bardzo szczegółowe opisy kostiumów, scenografii, a także realizacji przedstawień pozwalały na wykorzystanie tej metody pracy z dziećmi i młodzieżą. Oprócz walorów estetycznych tekst niósł wartości wychowawcze, moralne i patriotyczne.

Wśród autorów znaleźli się m.in: Maria Gerson-Dąbrowska, Hipolita Gnoińska, Maria Juszkiewiczowa, Ewa Szelburg-Zarembina, Benedykt Hertz, Klementyna Czaki, Maria Kownacka, Lucyna Krzemieniecka, N. Łabacz-Krzepkowska, Feliks Zahora, Zofia Koskowa, Antoni Bogusławski.

Najliczniejszą grupę stanowiły utwory publikowane w serii „Teatr Szkolny i Domowy". Teksty ukazywały się z przerwami od 1927 do 1936 roku4. Ogółem wydano 19 tytułów ${ }^{45}$.

Na szczególną uwagę zasługuje wkład „Naszej Księgarni” w propagowanie teatrzyku kukiełek jako formy dydaktyczno-wychowawczej i stworzenie repertuaru dla tej metody pracy ${ }^{46}$. Nakładem „Naszej Księgarni” w latach 1935-1937 opublikowano trzy tytuły w ramach serii „Biblioteka Teatrzyku Kukiełek” (numery 1 i 2 w 1935 roku, a numer 3 w 1937 roku).

Jako pierwszy wydano tekst Marii Kownackiej Bajowe bajeczki i świerszczowe skrzypeczki czyli O straszliwym smoku i dzielnym szewczyku, prześlicznej królewnie i królu Gwoździku, z ilustracjami Witolda Millera, w opracowaniu muzycznym J. Wesołowskiego. Sztuka była wówczas bardzo popularna, cieszyła się powodzeniem, wynikającym z żywej akcji, dużej dozy humoru i wdzięku ${ }^{47}$. Drugim tytułem w serii był tekst autorstwa Lucyny Krzemienieckiej Historia cała o niebieskich migdałach, w opracowaniu muzycznym J. Wesołowskiego. Autorka wielu książek dla dzieci stworzyła historię dziewczynki Stasi, która wszystkim chciałaby pomagać. Tekst został napisany rymowaną prozą i nadawał się zarówno na przedstawienie kukiełkowe, jak i zwykły teatr amatorski ${ }^{48}$. Ostatnim tomem serii były Cztery mile za piec Marii Kownackiej4, w opracowaniu muzycznym Anny Osser i z uwagami inscenizacyjnymi Henryka Ładosza.

Sztuki wydawane przez „Naszą Księgarnię”, przeznaczone do odegrania w szkole, zawierały pierwiastek dydaktyczno-wychowawczy. Propagowanie wła-

43 Obliczenia własne na podst.: M. Olczak-Kardas, Bibliografia...

44 W latach 1930-1933 nie wydano żadnego tytułu.

45 Np. M. Juszkiewiczowa, Kazia-leniuszek, Warszawa 1928; E. Szelburg-Zarembina, Złoty sen, Warszawa 1928. Obliczenia własne na podst.: M. Olczak-Kardas, Bibliografia...

46 „Nasza Księgarnia” wydała pierwszą na polskim rynku książkę dotyczącą teatru kukiełkowego. Redaktorem Teatrzyku kukiełek, opublikowanego w 1935 r., była Maria Kownacka, a w zespole opracowującym pojawili się: Jędrzej Cierniak, Joanna Landy, Aleksander Paliński, Witold i Helena Ulanowscy.

47 „Głos Nauczycielski” 1934/1935, nr 32, s. 617.

48 Tamże 1935/1936, nr 5, s. 93.

49 M. Kownacka, Cztery mile za piec, Warszawa 1937. 
ściwych zachowań było, oprócz samego wychowania estetycznego w ramach gry teatralnej, podstawowym celem tych tekstów. Przykładem może być sztuka M. Juszkiewiczowej Jak Bolek został harcerzem. Obrazek w jednej odsłonie, wydana w serii "Teatr Szkolny i Domowy” w 1927 roku (nr 3). Drugie wydanie pojawiło się w 1936 roku. Była to historia o Bolku, który koniecznie chciał zostać harcerzem, ale ze względu na to, że nie miał jeszcze 12 lat, aby osiągnąć wymarzony cel, musiał dokonać jakiegoś bohaterskiego czynu. Obrona sztandaru na obozie pozwoliła mu wcześniej złożyć przyrzeczenie harcerskie. W treść udało się autorce wpleść dziesięć przykazań harcerskich. W omówieniach tego tekstu pojawiały się stwierdzenia, że jest to miły obrazek z życia harcerzy, pełen humoru, żywej akcji, a przede wszystkim posiadający ogromne walory wychowawcze ${ }^{50}$.

Ta sama autorka w 1928 roku opublikowała w „Naszej Księgarni” sztukę Kazia-leniuszek. Obrazek sceniczny w jednej odsłonie, która ukazała się w ramach tej samej serii. Tekst napisany prozą, przeplataną wierszami A. Bogusławskiego.

$\mathrm{Na}$ uwagę zasługują teksty E. Szelburg-Zarembiny. Utwory sceniczne pisane przez nią otrzymywały bardzo pozytywne recenzje, w których podkreślano kunszt poetycki autorki. O utworze Za siedmioma górami. Baśń sceniczna, z ilustracjami M. Bukowskiej, który wydano w 1928 roku w serii „Teatr Szkolny i Domowy”, pisano: „Jest to jeden z najpiękniejszych utworów scenicznych, jaki ukazał się w ostatnich czasach. Polecić ją można nie tylko do odegrania, ale również jako lekturę"51.

W tym samym roku w ramach wspomnianej serii autorka wydała zbiór obrazków scenicznych pod wspólnym tytułem Zabawa, jakich mało! Oraz trzy inne obrazki sceniczne. Poszczególne obrazki różniły się długością - od pięciu do jednej odsłony. W recenzjach podkreślano poezję i fantazję zawarte $w$ tekście oraz melodyjność wiersza ${ }^{52}$.

Kolejna sztuka E. Szelburg-Zarembiny, Złoty sen. (Z życia dziewcząt). Obrazek sceniczny w jednej odsłonie, zakończony żywym obrazem, wydana w 1928 roku w ramach serii „Teatr Szkolny i Domowy”, poruszała kwestie patriotyczne i zawierała elementy wychowania obywatelskiego. Mogła być wykorzystywana na uroczystościach szkolnych o charakterze narodowym. Pod wpływem słów postaci historycznych, jak królewna Wanda, królowa Jadwiga i Emilia Plater, leniwa i pusta dziewczyna zmieniła swoje postępowanie. Postanowiła wstąpić do harcerstwa, które traktowała do tej pory lekceważąco. Chciała w ten sposób służyć ojczyźnie ${ }^{53}$.

Na uwagę zasługują również sztuki poświęcone świętom państwowym i religijnym. Boże Narodzenie było często wykorzystywanym tematem. Sztuka Feliksa Zahory W świętą noc. Obrazek sceniczny w 2-ch odsłonach (wydana w 1935 roku, seria „Teatr Szkolny i Domowy”, nr 15) to tekst pełen czarów i fantastycznych postaci (krasnoludów, gnomów, elfów), zawierający także elementy podkreślające polskość, np. „Aby Święte Dzieciątko ucieszyć, niosą Mu dary Polskiej ziemi:

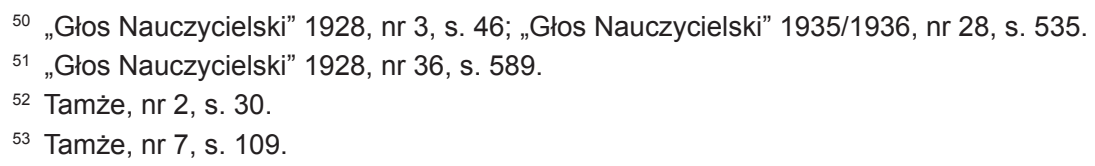


kryształy soli wielickiej, złote bursztyny bałtyckie, i węgiel ze Śląskiej ziemi, i Inu nitkami srebrnymi chcą okryć Maleńkiego, i chleb z pszenicy ziarna i polskie serca ofiarne składają u tronu Jego"54.

Treści, które za pomocą omawianych publikacji przekazywano, stanowiły ważny wkład w wychowanie młodego pokolenia. Poprzez podkreślanie polskości, historii kraju, życiorysów wybitnych Polaków, propagowano odpowiednie postawy społeczne, obywatelskie i patriotyczne. Promowano idee harcerstwa, zdrowia, sportowego ducha, nawyk oszczędzania, dbałość o przyrodę, a także zasady uczciwego życia. Uwypuklano takie cechy, jak: honor, przyjaźń, duma, obrona słabszych. Była to także nauka funkcjonowania w warunkach nowoczesnego, niepodległego państwa.

W tekstach dla dzieci i młodzieży znalazły się również tak istotne tematy, jak: współpraca i współzależność narodów ${ }^{55}$, rozwijanie uczuć społecznych ${ }^{56}$. Poświęcono także uwagę osobom niepełnosprawnym, uwrażliwiając młodych ludzi na ich problemy, pokazując stosunek społeczeństwa do niewidomych. Zwracano uwagę na ich potrzeby i uczucia oraz znaczenie miłości bliźniego ${ }^{57}$.

Wiele miejsca zajmowała przyroda, a szczególnie zwierzęta i ich traktowanie. Warto przypomnieć motto z książki Marii Gerson-Dąbrowskiej Najmilsi, które w pełni oddaje znaczenie i wagę, jaką do tego tematu przywiązywało wydawnictwo: „Obojętnego na niedolę zwierząt i ludzka niedola nie wzruszy”58.

Tematem utworów było także życie codzienne i obowiązujące w nim zasady stosunków międzyludzkich. Dzieci czytały o: przyjacielskiej solidarności, miłości między rodzeństwem, wdzięczności za gościnę, miłości i poświęceniu córki dla ojca ${ }^{59}$. Zetknięcie z prawdziwym życiem, ludzkimi postawami, a przez to poznawanie pewnych wartości i obowiązujących zasad było właściwym działaniem w przypadku młodego czytelnika.

Książki „Naszej Księgarni” odznaczały się niską ceną i bogatą szatą graficzną. Wydawnictwo dbało o estetykę książek dla najmłodszych. Warto zwrócić uwagę w tym miejscu na twórców okładek i ilustracji60.

W toku prowadzonych badań udało się ustalić twórców okładek do niektórych tytułów książek dla dzieci i młodzieży. Najwięcej zaprojektowali Konstanty Sopoćko i Bolesław Bakke. Pozostali twórcy to: Anna Chamcówna, Zofia Jakimowiczówna, Jan Klukowski, Ksawery Koźmiński, K. Kryński, Tadeusz Kryszak, Wiktor Zbigniew Langner, Jan Samuel Miklaszewski, J. Pakulski, Irena Pogorzelska, Edyta Gałuszkowa-Sicińska.

Książki dla dzieci i młodzieży ilustrowali: Antonina Dunin-Sulgustowska, Stanisław Zalewski, Jerzy Radlicz, Konstanty Sopoćko, Stanisław Bobiński, Molly

54 Tamże 1935/1936, nr 14, s. 278-279.

55 Np. S. Baczyńska, Żoko za granicą. Książka dla młodzieży, Warszawa 1930.

56 Np. J. Ciembroniewicz, Antek Sikora. (Jak to on w szkółce powszechnej Polskę budował), Warszawa 1928.

57 L. Durdikowa, Dzieci o wygasłych oczach, Warszawa 1935.

58 M. Gerson-Dabrowska, Nasi przyjaciele, Warszawa 1928.

59 M. Juszkiewiczowa, Małpka i krabik. Bajki japońskie, Warszawa 1935.

60 Część nazwisk została już raz wymieniona przy omawianiu serii wydawniczych. 
Bukowska, Tadeusz Gronowski, Zofia Stryjeńska, Wacław Teofil Radwan, Kamil Mackiewicz, Wanda Wóycicka, Wanda Zawidzka, Stanisław Łuckiewicz, Bolesław Bakke, N. Karmazyńska-Wdowiszewska, S. Sarkan, Wiktor Zbigniew Langner, K. Banasińska, Walter Trier (niemiecki tekst), Zofia Jakimowiczówna, Jan Samuel Miklaszewski, Jan Klukowski, Irena Pogorzelska, Edyta Gałuszkowa-Sicińska, Halina Maszyńska, K. Kryński, Tadeusz Kryszak, Wanda Pawłowska, Jadwiga Hładko, Janina Tyszkiewiczowa, Karolina Lubliner-Mianowska, Ewa Śliwińska, Alina Chylińska, Ksawery Koźmiński, M. Zajączkowski, Z. Wyszyński ${ }^{61 .}$

$W$ dostępnych materiałach rzadko można znaleźć informacje o ilustratorach związanych z „Naszą Księgarnią”. Janina Broniewska opisała we wspomnieniach swoją współpracę z Janem Klukowskim przy wydawaniu Przygód gałgankowej Balbisi ${ }^{62}$. J. Klukowski był przyjacielem pisarki z Kalisza i studentem architektury. Wspólną pracę nad książką J. Broniewska wspominała: „Maszynopis oddałam »Naszej Księgarni«. Cykl produkcyjny nie musiał być przewlekły. Janek wywiązał się ze swej części ilustracyjnej jakby sam miał koralikowe oczka: - A skąd wiedziałeś, że tak to widziałam? - spytałam ilustratora nie Balbisinym a własnym głosem. - Bo się przyjaźnimy nie od dziś... - odburknął"63. J. Broniewska pisała w swoich wspomnieniach o J. Klukowskim, że był małomówny, nie uzewnętrzniał swoich uczuć, ale potrafił słuchać zwierzeń na różne tematy, od filozoficznych po sprawy życia codziennego.

Zofia Stryjeńska współpracowała tylko przy jednej publikacji wydanej przez „Naszą Księgarnię" - Jaś $i$ Kasia, autorstwa Janiny Porazińskiej. Nakładem spółki ukazały się trzy kolejne wydania. Książka J. Porazińskiej osnuta była na motywach pieśni ludowej, stąd też wiele akcentów folklorystycznych w ilustracjach. Jaś występował w stroju krakowskim, a Kasia miała zwykły strój chłopki. Na ilustracjach widoczne są także inne elementy folklorystyczne, np. gaik niesiony przez dziewczęta, w tle drzwi do wiejskiej chaty. Ilustracje umieszczono na tablicach. W opracowaniach podkreśla się, że są proste i utrzymane w konwencji ludowego malarstwa, zachwycają „ruchem, niekiedy pędem, każdy z nich ma w sobie ukrytą akcje" ${ }^{4}$. Każda z ilustracji stworzona została w jednym kolorze, z dodatkiem czerni - żółty, zielony, niebieski, czerwony. W jednej z recenzji napisano: „Kilka podanych tu wierszy daje pojęcie o utworze i formie językowej, szkoda, że nie można "zacytować« prześlicznych obrazków, jakie wykonała do tej książki Zofia Stryjeńska. Każdy z obrazków jest w innym kolorze. Wszystkie doskonale harmonizują z treścią. Druk książki staranny, papier bezdrzewny”65.

Oprócz ilustracji zwracano uwagę na papier, druk. Wartości dodawały autentyczne zdjęcia, bardzo dokładne fotografie. Miało to znaczenie szczególnie przy

61 Często jeden twórca był odpowiedzialny za całą szatę graficzną książki, stąd też nazwiska powtarzają się w obydwu wymienionych grupach.

62 J. Broniewska, Przygody gałgankowej Balbisi, Warszawa 1936.

63 Taż, Tamten brzeg mych lat, Warszawa 1973, s. 116.

64 M. Jazowska-Gumulska, Elementy folkloru w ilustracji książki dziecięcej na przykładzie sztuki ilustratorskiej Zofii Stryjeńskiej, [w:] Sezamie, otwórz się! Z nowszych badań nad literaturą dla dzieci i młodzieży w Polsce i za granicą, red. A. Baluch, K. Gajda, Kraków 2001, s. 305.

65 „Głos Nauczycielski” 1932/1933, nr 15-16, s. 288. 
pracach popularnonaukowych, a także książkach ukazujących dzieciom i młodzieży nieznane kraje, zwierzęta, ludzi.

Książki dla dzieci i młodzieży o tematyce popularnonaukowej były zaopatrzone w aparat naukowy. Niejednokrotnie teksty posiadały przypisy rzeczowe, głównie o charakterze definicyjnym i słownikowym. Autorzy wyjaśniali trudne terminy, uściślali pewne kwestie, rozwijali temat. Warto zwrócić uwagę, że przypisy występowały również w utworach wierszowanych, np. w książce J. Porazińskiej Jaś i Kasia, w której pojawiło się wiele niezrozumiałych dla dzieci wyrazów pochodzących z gwary ludowej lub już przestarzałych ${ }^{66}$.

Wybór trudnych wyrazów i sposób ich wyjaśniania był dostosowany do poziomu odbiorców. Przykład - objaśnienie wielkości jednostki, jaką jest miliard - „miliard = 1000 milionów = 1000000 000; a milion = 1000 tysięcy = 1000 000"67, lub objaśnienia nieznanych pojęć, np. 'Nieprzebyty las podzwrotnikowy' (objaśnienie do słowa dżungla); 'Ptaszek wielkości owada' (objaśnienie do słowa koliber) ${ }^{68}$. Przypisy umieszczano na dole strony lub na końcu tekstu.

Często pojawiały się różnego rodzaju spisy. Oprócz spisu treści zamieszczano np. „Spis dzieł naukowych i popularnych o lesie”, „Spis nazw roślin przytoczonych w »Naszym lesie«”, „Spis rycin”69; „Spis łacińskich nazw roślin”, „Spis polskich nazw roślin"70. Pojawiała się także bibliografia, zawierająca literaturę przedmiotu lub publikacje danego autora. Na uwagę zasługują słowniczki terminów, np. „Słowniczek objaśniający trudniejsze terminy użyte w tekście” (układ według działów, a w ich obrębie alfabetyczny) ${ }^{71}$; „Słowniczek nazwisk” (zawierał krótkie notki biograficzne $)^{72}$.

Widoczny jest brak konsekwencji w tworzeniu aparatu naukowego - zawartości i formie przypisów, ich oznaczaniu, umieszczaniu spisu treści. Nawet w wydawnictwach seryjnych nie było ustalonych zasad.

Swoistym podsumowaniem rozważań na temat książek dla dzieci i młodzieży w repertuarze wydawniczym „Naszej Księgarni” może być cytat z recenzji zamieszczonej w „Głosie Nauczycielskim”: „Należy się [...] uznanie „Naszej Księgarni«, która nie szczędzi trudu w dokompletowaniu wartościowych utworów dla dziatwy, wypełniając tym swe powołanie wydawnictwa będącego w rękach nauczycielstwa"73.

Korzystna dla spółki była możliwość reklamowania własnych wydawnictw w organie prasowym ZNP, docierającym do znacznego grona odbiorców. Recenzje i reklamy książek dla dzieci i młodzieży zamieszczane w „Głosie Nauczyciel-

66 J. Porazińska, Jaś i Kasia, Warszawa 1936.

${ }^{67}$ F. Budrecki, Polskie niebo, Warszawa 1936.

68 M. Juszkiewiczowa, O dużym Tomku, Warszawa 1939.

${ }^{69}$ M. Sokołowski, Nasz las, Warszawa 1938, Seria „Ze Świata Przyrody”, nr 9.

70 T. Cygowa, H. Karmazyńska-Przewalska, Nasze rośliny wiosenne, Warszawa 1935, Seria „Ze Świata Przyrody", $\mathrm{nr} 2$.

71 Tamże.

72 J. Dembowski, Darwin, Warszawa 1936, Seria „Ze Świata Przyrody”, nr 4.

${ }^{73}$ H. Kodź, [Recenzja książki - J. Grabowski, Kochany zwierzyniec], „Głos Nauczycielski” 1938/1939, nr 26, s. 604. 
skim" miały wpływ na kompletowanie księgozbiorów bibliotek szkolnych, a także zawartość spisów dodatkowych lektur polecanych przez nauczycieli - „Nigdzie żadnych morałów, żadnych specjalnych pouczeń przyrodniczych, ale taka właśnie książka dużo da dziecku. Będzie to jedna z najmilszych książek jako upominek gwiazdkowy i jedna z najmilszych w bibliotece szkolnej dla młodszych"74.

W przypadku książek dla dzieci i młodzieży wydawanych przez „Naszą Księgarnię", odbiorca mógł być pewien, że publikacje zawierają odpowiednie treści, co dawało firmie przewagę nad innymi wydawnictwami. Wielokrotnie w opiniach i recenzjach omawianych tekstów wskazywano jako adresatów książek dla dzieci i młodzieży także nauczycieli oraz dorosłych, którzy również powinni poznać treści zawarte $w$ tych książkach. Mogło to pomóc we właściwym ukierunkowaniu pracy z młodymi ludźmi.

Spółce udało się pozyskać do współpracy wybitnych polskich autorów, którzy tworzyli wówczas dla młodych odbiorców. Warto wymienić znane nazwiska, m.in.: Janina Porazińska, Ewa Szelburg-Zarembina, Janina Broniewska, Maria Gerson-Dąbrowska, Jan Grabowski, Stefania Baczyńska, Bohdan Dyakowski, Czesław Centkiewicz, Jan Bogumił Sokołowski. Oprócz tego tworzenie szaty graficznej książek przez takich twórców jak Konstanty Sopoćko czy Zofia Stryjeńska świadczy wyraźnie o poważnym traktowaniu najmłodszych odbiorców, których gust czytelniczy i zamiłowanie do książek kształtuje się w okresie dzieciństwa.

Książki dla młodego odbiorcy wydawane nakładem „Naszej Księgarni” odznaczały się wartościowym tekstem, bogatą szatą graficzną i niską ceną, a ich niezaprzeczalnym atutem było ścisłe powiązanie z potrzebami szkoły.

74 [Recenzja książki - E. Szelburg-Zarembina, Najmils], , „Głos Nauczycielski” 1927, nr 2, s. 761. 